\title{
Awareness of Custom Officers on Counterfeit Pharmaceutical Products And The Roles Of Pharmacy Enforcement Officers
}

\author{
Chuo Yew Ting', Hiram Ting ${ }^{2}$, Yee Chang Soh ${ }^{3}$, Abu Hassan AAJ', Kah Seng Lee ${ }^{5}$ \\ 'Sarawak Pharmacy Enforcement Branch, Sarawak State Health Department, Sarawak, MALAYSIA. Institute of Borneo Studies, Universiti Malaysia Sarawak, Sarawak, \\ MALAYSIA. \\ ${ }^{2}$ Sarawak Research Society, Sarawak, MALAYSIA. Institute of Borneo Studies, Universiti Malaysia Sarawak, Sarawak, MALAYSIA. \\ ${ }^{3}$ School of Pharmacy, Monash University Malaysia, Bandar Sunway, Selangor, MALAYSIA. \\ ${ }^{4}$ Sarawak Pharmaceutical Service Division, Sarawak State Health Department, Sarawak, MALAYSIA. \\ ${ }^{5}$ Pharmaceutical Services Divisions, Ministry of Health, Selangor, MALAYSIA
}

\begin{abstract}
Background: Counterfeit pharmaceutical products (CPP) is a lucrative business for illegal operators who constantly try to smuggle their products into Malaysia. Full understanding of the roles and duties of pharmacy enforcement division as well as CPP by Royal Malaysian Custom (RMC) officers are pre-emptive to optimize the operation against drug smuggling. Objective: This study is aimed to examine the awareness of RMC officers on CPP and the roles of Pharmacy Enforcement Division (PED) officers at custom ports. Methods: A self-administered structured questionnaire was developed based on the review of relevant Acts and Guidelines. The questionnaire was reviewed by 4 key officers and pre-tested. Stratified purposeful sampling was adopted to recruit RMC officers who worked at 16 custom ports in Sarawak where PED officers were stationed. Ethics approval and permission to collect data were obtained prior to data collection. Results: A total of $110 \mathrm{RMC}$ respondents (48.9\% response rate) were sampled. As a whole, the mean scores of awareness level towards CPP and the roles of PED officers are satisfactory at $4.12( \pm$ SD 0.967) and $4.21( \pm S D 0.785)$ respectively. RMC officers who have worked for more than 10 years are significantly having greater awareness towards
\end{abstract}

CPP as compared to those who have worked for 10 years or less. Conclusion: This study reveals that the awareness of RMC officers towards CPP and the roles of PED officers are sufficient to curb the entering of CPP through the collaboration of PED officers. However, the awareness program for the RMC officers who have less experience is necessary to reinforce their understanding of CPP.

Key words: Awareness, Counterfeit Pharmaceutical Products, Pharmacy Enforcement Division, Royal Malaysian Custom Officer.

Correspondence :

Ting Chuo Yew

Jalan Diplomatik, Off Jalan Bako, 93050 Petra Jaya, Kuching,

Sarawak, MALAYSIA.

Phone no: +60168605496

Email: tingchuoyew@gmail.com

DOI: 10.5530/jyp.2017.9.50

\section{INTRODUCTION}

Counterfeiting is a thriving industry and is considered as one of the most profitable occupations in the world. ${ }^{1}$ Consequently, the types of products being counterfeited have expanded from luxurious goods to inevitably health related products, especially pharmaceutical products. ${ }^{2}$ Unlike other tangible goods, the spread and use of counterfeit pharmaceutical products (CPP) have not only violated the intellectual property rights of the proprietary drug company, ${ }^{3}$ but have also had negative impact on public health. The World Health Organization (WHO) describes CPP as a silent epidemic which can cause drug resistance and death. ${ }^{4} \mathrm{WHO}$ further states that the projected rate of counterfeit medicines among the global medicines trade is as high as $10 \% .{ }^{5} \mathrm{In}$ fact, the problem is expected to be much more severe than what is reported if not due to difficulties in detecting the illegal trades. ${ }^{6}$ Hence, some nations had imposed a compulsory pharmaceutical product's security features as a measure to detect counterfeiting despite additional cost incurred to pharmaceutical companies. $^{7}$ Although pharmaceutical counterfeiting is a perennial conundrum worldwide, Asia is reported to be the top region most frequently linked to pharmaceutical crime activities. ${ }^{8}$ The rampancy of pharmaceutical counterfeiting is not only due to failures to enforce the laws effectively but also the exploitation of deficiency in border control. ${ }^{8}$ Hence, the smuggling and illegal importation of CPP remain rife in many countries in Asia.
In Malaysia, the baseline on the prevalence of CPP was reported to be approximately $6 \%$ in 1997 and there was a slight decrement to $5 \%$ in $2005 .{ }^{9}$ According to the report of World Health Professions Alliance, the value of CPP confiscated was about MYR 18.4 million in $2006 .{ }^{8}$ In the following year, the value of seizures was recorded higher as much as MYR 35.8 million. Malaysia reported its biggest seizure in year 2010 when the custom officers seized a container from Singapore loaded with 142 boxes of CPP. ${ }^{10}$ In addition to the aforementioned, a surprising confiscation by the Ministry of Health at Port Klang in 2009 revealed a million pills of counterfeit Viagra alongside with millions of pseudoephedrine, the latter of which was the precursor to the manufacturing of hard drug Methamphetamines. ${ }^{9}$ These seizures have no doubt implicated the massive scale of pharmaceutical syndicates that have been undermining the existing public health system. In responding to the issues on hand, the Minister of Health urged for stricter checks on medicine imports with more rigid collaboration with the Royal Malaysian Customs (RMC) Department. ${ }^{11}$ Such collaboration was strongly encouraged by WHO. Nevertheless, the awareness of relevant authorities in combating the importation and trading of CPP through education was highlighted as one of the key objectives in the Declaration of Rome. ${ }^{5}$

The RMC Officers are appointed under Section 4 of Customs Act 1967 (Laws of Malaysia, Act 235). Under Section 112 to Section 114 of the

This is an open access article distributed under the terms of the Creative Commons Attribution-NonCommercial-ShareAlike 4.0 License, which allows others to remix, tweak, and build upon the work non-commercially, as long as the author is credited and the new creations are licensed under the identical terms. 
Act, the RMC Officers are given power to screen on the importation of goods and possessions of the persons who enter the country. "Customs" is known as a tax-gathering arm of government and is responsible for screening possessions of those who enter the country or bring goods in. ${ }^{12}$ As such, Customs has significant roles in health-related function, and that includes halting illicit drugs and hazardous products together with the public health authorities. ${ }^{12}$ On the same note, under the Custom Act 1967 (Act 235, Law of Malaysia), the RMC officers are given authority to open packages and examine goods as well as seizing them at custom ports if there is "reasonable cause to suspect that there has been committed any offence against this Act or any regulation made thereunder, or any breach of any of the provisions of this Act or of any regulation made thereunder or of any restriction or condition subject to or upon which any license or permit has been granted". At the same time, the Regulation 7(1) Control of Drugs and Cosmetics Regulations 1984 stipulate that the importations of pharmaceutical products are prohibited except under an import license or permit from relevant authorities, such as Pharmacy Enforcement Division (PED) under Ministry of Health Malaysia. Under the umbrella of PED, each state has its own Pharmacy Enforcement Branch to provide services within the region. At custom port, PED officers act as technical advisors to the RMC officers regarding the screening of commodities classified under the tariff code which are controlled by PED. ${ }^{13}$ Subsequently, PED officers may provide suggestion to the RMC officers to seize and forfeit consignment that contravenes the Laws and Regulations enforced by PED.

By knowing the roles of both RMC and PED at the custom ports in preventing the entry of CPP, the collaboration between both sides are highly dependent on their awareness towards the roles of one another. ${ }^{13}$ The positive correlation between awareness and adoption of service is well supported by extant literatures. ${ }^{14,15}$ However, given the fact that information pertaining to CPP is contained in the Drug Registration Guidance Document under Ministry of Health Malaysia, the RMC officers might not be fully aware or have vivid understanding about the implication of such policy towards them in combating the entering of CPP. Hence, without substantial awareness towards such policy, the RMC officers might fail to work collaboratively with PED in addressing CPP. It can be concluded that the effectiveness of detecting and seizing the CPP is hinged upon high awareness of custom officers towards the CPP and the roles of PED.

Confining to Sarawak, a state of Malaysia and an emerging market in Asia, it has the largest territory and also the most custom ports compared to other states. ${ }^{16}$ According to the report of PED, there are nine borders between Sarawak and Kalimantan, Indonesia which do not have PED officers due to lack of manpower and logistic problem. ${ }^{16}$ This puts the state at higher risk of becoming points of CPP importation. The other states also report similar problems, where the incumbent PED officers are unable to cope with the demand at custom ports. This inevitably provides the smugglers opportunity to exploit the shortcomings by bringing in CPP without being detected by law enforcers. This is reflected from the number and value of seizures of CPP in the Malaysian market as mentioned earlier.

To date, there is very minimal information pertaining to the level of awareness of RMC officers towards CPP since little is studied and documented in academic literature and RMC official website. ${ }^{17}$ However, such information is critically important and would serve as a baseline study in planning the awareness-rising strategy to ensure the roles of RMC officers in combating CPP are upheld and reinforced. Hence, the present study is a step towards the right direction by examining the awareness level of RMC officers towards CPP and the roles of PED officers in Sarawak and Asiatic region.

\section{MATERIALS AND METHODS}

The study used both qualitative and quantitative approaches in a sequential manner, with the focus on the latter approach. The relevant Acts and Guidelines were firstly reviewed and content-analysed so as to generate items pertaining to the awareness towards CPP and the roles of PED. These items were then incorporated into a self-administered and structured questionnaire. By combining both approaches, it is believed that the study would yield findings which are more insightful and relevant to the phenomenon under investigation. ${ }^{18}$

The target population of this study was the RMC officers at custom ports in Sarawak where PED officers were also stationed. Those RMC officers operating at custom ports without PED officers were thus excluded because they had limited exposure to PED officers and thus their awareness towards the roles of PED officers would be biased. As such, stratified purposeful sampling was deemed most appropriate to sample the respondents. ${ }^{19}$

Official consent by Director of Sarawak RMC Department was obtained to conduct the research and collect data from the RMC officers prior to the study to ensure ethical issues were not compromised. Subsequently, paper questionnaire was distributed to all RMC officers at custom ports who fulfilled the criterion in order to get desirable sample size and facilitate analysis with adequate statistical power. ${ }^{20}$

Every respondent was given an informed-consent document before attempting the questions to show that they were fully aware of and understood the purpose of the study, and that they were willing to participate in the survey voluntarily. Once the questionnaire was completed, the officers returned the questionnaires by putting them into a black box prepared by the researchers. The period of data collection was from $24^{\text {th }}$ June 2016 until $10^{\text {th }}$ July 2016.

The relevant Acts and Guidelines were firstly reviewed by the researchers using content analysis. ${ }^{16,24}$ The coded data were then constructed as statements and listed in separate columns, one for the awareness towards CPP and another for the awareness towards the roles of PED. Four key informants from PED and Sarawak RMC department were invited to examine the statements to further ascertain their relevance, thus enhancing the validity of the content. Together with the researchers, discussions and revisions on wordings were done based on joint knowledge and experiences to omit ambiguous, irrelevant and redundant items. ${ }^{21,22}$ Besides, five RMC officers were selected as pre-test sample. They were asked to explain to the researchers their understanding of every statement to ensure there was no discrepancy between the intended meaning and the interpreted meaning of the statements.

Once it was all done, the self-administered and structured questionnaire was designed. It consisted of three sections, namely demographic characteristics (Part A), the awareness towards CPP (Part B) and the awareness towards the roles of PED officer (Part C). Categorical scale was used in Part A whereas five-point Likert scale anchoring two ends of agreeability was utilized in Parts B \& C. The informed consent was enclosed as the first page of the questionnaire and it contained the description of the purpose of the study as well as assuring the confidentiality and anonymity of the respondents. The statements were written in Bahasa Melayu (Malaysian official language) by using collaborative translation to ensure that the respondents understood the words, statements and instructions, filled up the questionnaire at their comfort, and most importantly gave valid responses.

A total of 225 copies of questionnaire were distributed to all target officers in 16 RMC institutes throughout Sarawak. A total of 122 copies were subsequently collected, which yielded a response rate of $54.2 \%$. However, 12 copies were found to have straight-lining responses and missing values, thus they were removed from the observation. A total of 
110 usable copies were retained with an effective response rate of $48.9 \%$ for data entry and analysis. Statistical Package for Social Science (SPSS) version 21.0 was used whereby Frequency and Descriptive analyses were performed to describe the awareness towards CPP and the roles of PED officers, as well as independent t-test and ANOVA to test the difference of awareness by demographic characteristics.

\section{RESULTS}

Table 1 shows the demographic profile of the 110 RMC officers sampled at custom ports throughout Sarawak. It is evident that most of the respondents are assistant officers and majority of them have no more than 10 years' length of service. Understandably, most of them are sampled at Kuching division as it is the capital city of Sarawak. It is worth noting that most officers have their highest education at secondary school level. To interpret the level of awareness towards CPP and the roles of PED, it is useful to define it based on the mean scores with practical meaningfulness. Using the two anchors of agreeability, the mean score of 2.50 or less is defined as "very little awareness". Despite being above midpoint, the mean scores from 2.51 to 3.50 and from 3.51 to 4.00 are defined as "little awareness", and "moderate awareness" respectively as RMC officers are expected to be well aware of CPP and the roles of PED to fulfil their obligation to curb the importation of CPP effectively. Hence, a mean score of 4.01 or above is regarded as "high awareness", and only such level of awareness is deemed satisfactory. Results are illustrated in Table 2.

Generally, the awareness level towards CPP (mean=4.04) and the roles of PED officers (mean=4.16) are high, with the mean scores of 4 and above. However, it is necessary to point out that the RMC officers only have moderate awareness about CPP without the registration number on the product label (mean $=3.97$ ). This could denote a potential loophole in the effort to curb the entry of CPP.

Comparisons of major variables with demographic characteristics are carried out. Table 3 shows that no significant difference is found between groups based on position, and division of duty with regard to the awareness towards CPP and the roles of PED officers, except for length of service. Post Hoc Bonferroni Test reveals that the RMC officers who have worked more than 10 years are significantly different from those who have worked less. It is no surprise that the former have greater awareness towards CPP than the latter. Nevertheless, what is striking is the fact that the RMC officers with 10 years or less experience are not well aware of $\mathrm{CPP}$ as one would hope for (mean $=3.76$ and 3.83 ).

\section{DISCUSSION}

In general, the awareness of RMC officers towards CPP is high. However, their awareness on the features of CPP specifically is comparatively lower, which is rated as $79.4 \%($ mean $=3.97)$ and $81 \%($ mean=4.1). Such awareness is deemed to be crucial for the RMC officers to detect CPP at custom ports. The mechanism of identifying CPP in Malaysia has been convenient to authorities and general public since policy makers have enacted a compulsory registration process for all pharmaceutical products by Drug Control Authority under the umbrella of Ministry of Health Malaysia. ${ }^{23}$ Nonetheless, such enactment is a substantial move to safeguard the quality, safety and effectiveness of all pharmaceutical products in the country. ${ }^{23}$ With such enactment, two features to differentiate a registered pharmaceutical product from an unregistered pharmaceutical product or CPP are compulsorily imprinted on the outer packaging of every pharmaceutical product, namely registration number and Meditag ${ }^{\mathrm{TM}}$ Hologram. ${ }^{23}$ Similar measure to prevent the counterfeiting of medicine is taken by U.S. through the introduction of drug pedigree. ${ }^{24}$ The ability to identify the features of registered pharmaceutical products has basically enabled the general public and relevant authorities to iden- tify CPP. According to National Survey on the Use of Medicine in year 2012, the level of awareness on the pharmaceutical product registration among general public was found to be $85.9 \%{ }^{25}$ The lower level of awareness among the RMC officers compared to general public has urged the PED to provide an immediate and comprehensive exposure to the RMC officers on the mechanism of identifying CPP. On the other hand, the awareness level of RMC officers towards the roles of PED is found high (mean $>4.0$ ). Such awareness level shows the RMC officers are more likely to recognize the importance of their roles and accept services provided by PED. ${ }^{14,15}$

Awareness level of RMC officers on the roles of PED officers (mean=4.16), implies the mutual understanding between both departments. Scholars have suggested that such mutual understanding is crucial in enhancing the collaboration of both parties with minimal conflicts..$^{13}$ As mentioned earlier, information pertaining to CPP and the roles of PED is contained in the policies under Ministry of Health, thus such high level of awareness is strongly related to the long working relationship between two departments and also dialogue organized between two departments biannually. Besides, talks and exhibition related to CPP and the roles of PED have also been given by PED through invitation from RMC. The results supported the importance of close working relationship and further underscores a long-term collaboration between both departments in combating the entering of CPP into Sarawak through continuous awareness raising campaign among RMC officers.

In addition, the position of RMC officers does not have significant association with the awareness level towards CPP and the roles of PED officers. This finding is contrary to the finding of Mancinelli and Kafai, which claimed that the position in an organization hierarchy is a factor affecting the awareness towards organization policies. ${ }^{26}$ Apart from that, no significant difference is found between groups based on division of duty with regard to the awareness towards CPP and the roles of PED officers.

The length of services, however, is found to be a factor that significantly affects the awareness of RMC officers towards CPP. Specifically, RMC officers who have worked for more than 10 years have significantly greater awareness on CPP than those who have worked for 10 years or less. Hence, the awareness program for the RMC officers who have less experience (length of service not more than 10 years) should be prioritized. Given the fact that they make up more than half of the studied population $(56.1 \%)$, such program is of utmost importance to the new and less experienced officers. Through more focused awareness rising strategies, the collaboration between the RMC and PED personnel would be intensified in combating the importation and trading of CPP. As a result, the smuggling, illegal importation and supply of CPP into market will be reduced, which would in turn safeguard the wellbeing of the people.

Although the present study cannot correlate less awareness towards CPP to the importation of these products in Sarawak, the RMC officers at custom ports are expected to be well aware of CPP. It is thus essential to look into the matter and take remedial actions with urgency so as to reassess the severity of the importation and trading.

\section{Limitations of the Study and Suggestion for Future Research}

Notwithstanding the importance and implications of the study, there are a few limitations which are worth noting for consideration and future investigation. Firstly, only the RMC officers working at custom ports where the PED officers were on duty were sampled. This might limit the actual assessment of the awareness level of all RMC officers, especially those without the assistance of PED officers, because the RMC officers sampled in this study might have gained knowledge from the PED officers on duty. Secondly, despite being acceptable in survey research, the 
Table1: Demographic Profile of Respondents

\begin{tabular}{|c|c|c|c|}
\hline Demographics & Categories $(n=110)$ & $\begin{array}{c}\text { Frequency } \\
\text { (n) }\end{array}$ & $\begin{array}{c}\text { Percentage } \\
(\%)\end{array}$ \\
\hline \multirow[t]{2}{*}{ Position } & Officers & 20 & 18.2 \\
\hline & Officer Assistants & 90 & 81.8 \\
\hline \multirow[t]{8}{*}{ Length of services } & $0-5$ years & 32 & 29.1 \\
\hline & $6-10$ years & 30 & 27.3 \\
\hline & $11-15$ years & 8 & 7.3 \\
\hline & $16-20$ years & 11 & 10.0 \\
\hline & $21-25$ years & 3 & 2.7 \\
\hline & $26-30$ years & 7 & 6.4 \\
\hline & 31 - 35 years & 13 & 11.8 \\
\hline & $36-40$ years & 6 & 5.5 \\
\hline Academic & Primary School & 2 & 1.8 \\
\hline \multirow[t]{5}{*}{ Qualification } & Secondary School & 72 & 65.5 \\
\hline & Diploma & 17 & 15.5 \\
\hline & Degree & 18 & 16.4 \\
\hline & Master & 1 & 0.9 \\
\hline & $\mathrm{PhD}$ & 0 & 0.0 \\
\hline \multirow[t]{5}{*}{ Division of Duty } & Kuching & 61 & 55.5 \\
\hline & Sibu & 24 & 21.8 \\
\hline & Sarikei & 4 & 3.6 \\
\hline & Bintulu & 10 & 9.1 \\
\hline & Limbang & 11 & 10.0 \\
\hline
\end{tabular}

Table 3: Comparison of Major Variables with Demographic Characteristics

\begin{tabular}{|c|c|c|c|c|c|c|}
\hline \multirow[t]{2}{*}{ Demographics } & \multicolumn{2}{|c|}{$\begin{array}{l}\text { Awareness } \\
\text { towards CPP }\end{array}$} & \multirow{2}{*}{$\begin{array}{c}t / F \\
(p \\
\text { value })\end{array}$} & \multicolumn{2}{|c|}{$\begin{array}{c}\text { Awareness } \\
\text { towards Roles } \\
\text { of PED }\end{array}$} & \multirow{2}{*}{$\begin{array}{c}t / F \\
(p \\
\text { value) }\end{array}$} \\
\hline & Mean & SD & & Mean & SD & \\
\hline \multicolumn{7}{|l|}{ Position } \\
\hline Officers $(\mathrm{n}=20)$ & 4.21 & 0.721 & \multirow[b]{2}{*}{$\begin{array}{c}0.806 \\
(0.422)\end{array}$} & 4.43 & 0.678 & \multirow[b]{2}{*}{$\begin{array}{c}1.429 \\
(0.156)\end{array}$} \\
\hline $\begin{array}{l}\text { Assistant Officers } \\
\qquad(\mathrm{n}=90)\end{array}$ & 4.04 & 0.853 & & 4.16 & 0.813 & \\
\hline \multicolumn{7}{|l|}{ Length of Service } \\
\hline $0-5$ years $(n=32)$ & 3.76 & 0.734 & \multirow{3}{*}{$\begin{array}{c}9.497 \\
(0.001)\end{array}$} & 4.07 & 0.631 & \multirow{3}{*}{$\begin{array}{r}3.055 \\
(0.051)\end{array}$} \\
\hline $\begin{array}{c}6-10 \text { years }(\mathrm{n} \\
=30)\end{array}$ & 3.83 & 0.944 & & 4.03 & 0.984 & \\
\hline$>10$ years $(\mathrm{n}=48)^{*}$ & 4.44 & 0.671 & & 4.41 & 0.701 & \\
\hline \multicolumn{7}{|l|}{ Division of Duty } \\
\hline Kuching $(\mathrm{n}=61)$ & 4.02 & 0.846 & \multirow{5}{*}{$\begin{array}{c}0.747 \\
(0.562)\end{array}$} & 4.05 & 0.874 & \multirow{5}{*}{$\begin{array}{c}1.825 \\
(0.130)\end{array}$} \\
\hline Sibu $(n=24)$ & 4.12 & 0.871 & & 4.31 & 0.675 & \\
\hline Sarikei $(\mathrm{n}=4)$ & 4.00 & 0.490 & & 4.79 & 0.210 & \\
\hline Bintulu $(\mathrm{n}=10)$ & 4.48 & 0.612 & & 4.50 & 0.539 & \\
\hline Limbang $(\mathrm{n}=11)$ & 3.95 & 0.921 & & 4.39 & 0.611 & \\
\hline
\end{tabular}

* Post Hoc Bonferroni Test shows that the RMC officers who have worked more than 10 years are significantly different from those who have worked less $(\mathrm{p}<0.01)$.

Table 2: Awareness of RMC Officers towards CPP and Roles of PED officer

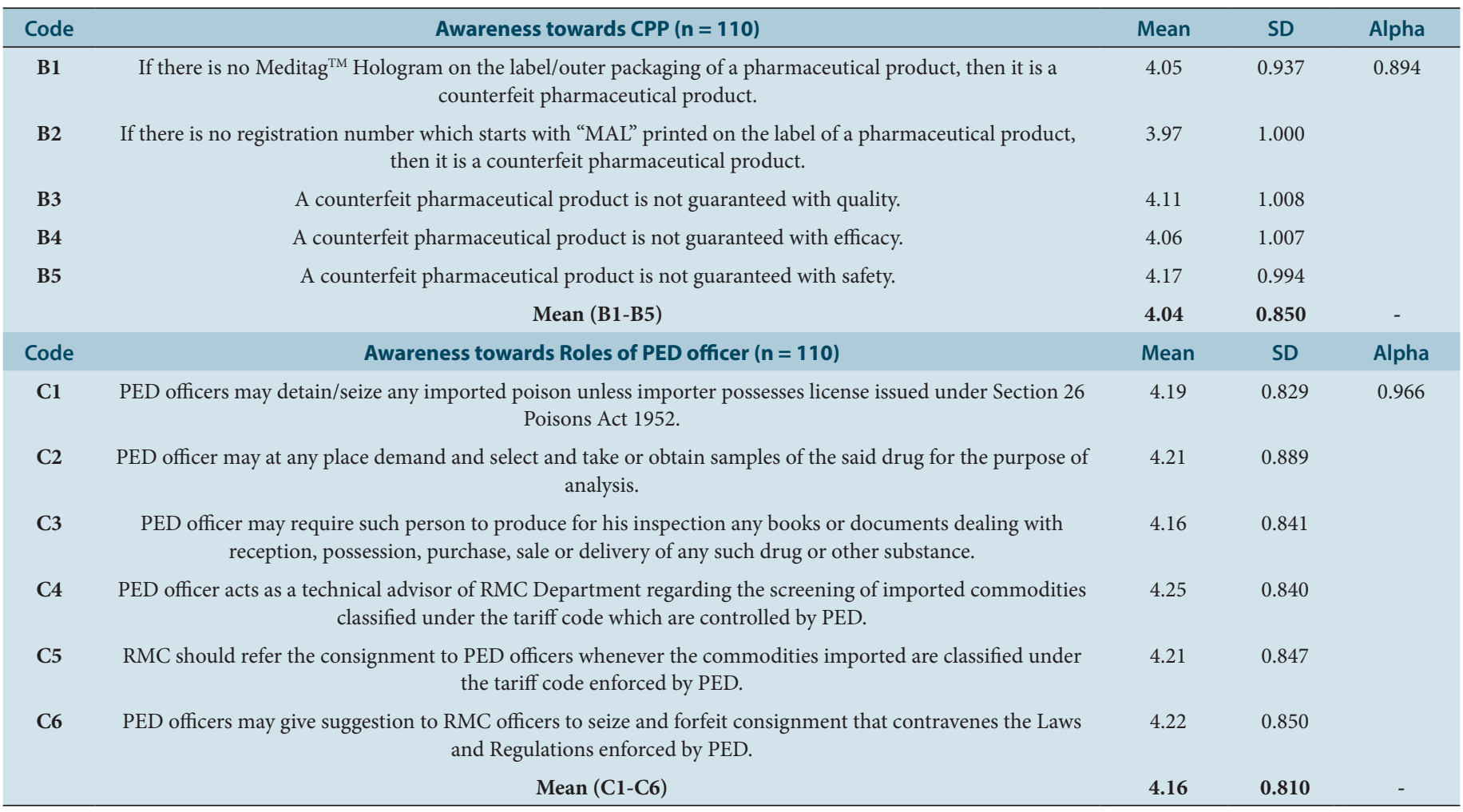


Ting et al.: Awareness of Custom Officers on Counterfeit Pharmaceutical Products And The Roles Of Pharmacy Enforcement Officers

non-response rate of the study could indicate the unwillingness of the RMC officers to expose their awareness level, given the fact that the study is approved by the director from the RMC department; hence creating statistical biases. ${ }^{27}$ However, scholars have argued that such high non-response rate may not necessarily induce statistical bias as the cut-off point for high or low non-response rate remains un-concluded..$^{28,29}$ Lastly, this study does not further examine the relationship between awareness and the practice of RMC officers on CPP. It is thus imperative to connect the cognitive aspect to the behavioural responses so as to assess its causality and determine how awareness would impact the actual practice to curb the importation and trading of CPP for the betterment of the community in Sarawak and Malaysia.

\section{CONCLUSION}

This study reveals that the awareness of RMC officers towards CPP and the roles of PED officers are sufficient to curb the entering of CPP through the collaboration of PED officers. However, the awareness program for the RMC officers who have less experience is necessary to reinforce their understanding of CPP. The findings of this study have provided essential insights to policy makers and officers of both RMC and PED departments in formulating strategies and solutions to increase the awareness of RMC officers towards CPP and the roles of PED.

\section{ACKNOWLEDGEMENT}

The authors would like to express their gratitude to Director General of Health Malaysia for his approval to publish this manuscript. The authors would like to thank the Director of Sarawak Royal Malaysian Customs Department for his approval on the data collection of this study. Last but not least, credits to all enumerators who devoted their efforts unreservedly in data collection process to make this study possible.

\section{CONFLICT OF INTEREST}

The authors declare having no conflict of interest.

\section{ABBREVIATIONS}

CPP: Counterfeit Pharmaceutical Products; DRGD: Drug Registration Guidance Documents; GISCP: Guideline of Importation Screening at Custom Ports; PED: Pharmacy Enforcement Division; PA'52: Poisons Act 1952; RMC: Royal Malaysian Custom; SODA'52: Sales of Drugs Act 1952; SD: Standard Deviation; WHO: World Health Organization.

\section{REFERENCES}

1. Wertheimer Al, Chaney NM, Santella T. Counterfeit pharmaceuticals: current status and future projections. J Am Pharm Assoc. 2003:43(6):710-8.

2. Bidin A. Counterfeit Medicine: A Threat to the Public Health and Pharmaceutical Industry. International Conference on Corporate Law [Internet]. 2009 [cited 2015 Sept 24]. Available from: http://www.unisza.edu.my/library/images/IDC/ counterfeit.pdf

3. Pol S, Janodia M, Jagadeesh P, Bhat K, Udupa N. Business method patents: A primer. J Young Pharm. 2009;1(4):379.

4. World Health Organization. Counterfeit Medicines: the silent epidemic [Internet]. 2006 [cited 2015 Sept 24]. Available from: http://www.who.int/mediacentre/news/releases/2006/pro9/en/.

5. World Health Organization. Declaration of Rome, WHO International Conference on Combating Counterfeit Medicine [Internet]. 2006 [cited 2015 Sept 24]. Available from: http://www.who.int//medicines/serious/counterfeit/Rome Declaration.pdf.

6. OECD. The Economic Impact of Counterfeiting and Piracy: Executive Summary. Organization For Economic Co-operation And Development [Internet]. 2007 [cited 2015 Sept 24]. Available from: https://www.oecd.org/sti/38707619.pdf.

7. Swain TR, Giri PP. Generic Medicines: Old wine in new bottle?. J Young Pharm. 2015;7(3):143

8. World Health Professions Alliance. Background Document on Counterfeit Medicines in Asia. Taiwan: WHPA [Internet]. 2011 [cited 2015 Jan 28]. Available from: http://www.whpa.org/counterfeit_campaign.htm.

9. Harris J, Stevens P, Morris J. Keeping it real: Combating the spread of fake drugs in poor countries [Internet]. 2009 [cited 2016 Feb 16]. Available from: http://www.ncpa.org/sub/dpd/index.php?Article_ID=18062.

10. Ministry of Health Malaysia. Malaysia Pharmaceuticals and Health Care Report. Malaysia: Ministry of Health [Internet]. 2010 [cited 2015 Jan 28]. Available from: http://www.moh.gov.my/images/gallery/ETP/NKEA\%20Penjagaan\%20Kesihatan.pdf.

11. Fernandez E. Strict Checks on Medicine Imports [Internet]. The New Straits Time. 2015 Jan 27 [cited 2015 Feb 1]. Available from: http://www.highbeam. com/doc/1P1-231994376.html.

12. John ML, editor. "customs". In: A Dictionary of Public Health. Oxford University Press [Internet]. 2007 (cited 2015 Jan 28). Available from: http://www. oxfordreference.com/view/10.1093/acref/9780195160901.001.0001/acref9780195160901-e-985.

13. Dourish P, Bellotti V. Awareness and coordination in shared workspaces. Proceedings of the 1992 ACM conference on Computer-supported cooperative work. 1992 Dec 1 (p. 107-114). ACM

14. McCaslin R. Reframing research on service use among the elderly: An analysis of recent findings. Gerontologist. 1988;28(5):592-9.

15. Wan TT. The behavioral model of health care utilization by older people. Aging and health care: Social science and policy perspectives. New York: Routledge; 1989. p. 52.

16. Pharmacy Enforcement Division; Ministry of Health, Malaysia. Garispanduan Saringan Pengimportan Di Pintu Masuk Kastam. Petaling Jaya: Pharmacy Enforcement Division; 2013.

17. Customs.gov.my [homepage on the Internet]. Putra Jaya: Royal Malaysian Customs Department [updated 2015 Jan 15; cited 2015 Feb 6]. Available from: http://www.customs.gov.my/ms (2015).

18. Cathain OA, Murphy E, Nicholl J. Three techniques for integrating data in mixed methods studies. BMJ. 2010;341:1147-50.

19. Tongco MD. Purposive sampling as a tool for informant selection. Ethnobotany Research \& Applications [serial on the Internet]. 2007 [cited 2015 Sept 22]; 5: p. 147-158. Available from: http://hdl.handle.net/10125/227

20. Baruch $Y$, Holtom BC. Survey response rate levels and trends in organizational research. Hum Relat. 2008;61(8):1139-60.

21. Cialdini RB, Frost MR, Newsom JT. Preference for consistency: the development of a valid measure and the discovery of surprising behavioral implications. J Pers Soc Psychol. 1995;69(2):318-28.

22. Puri R. Measuring and modifying consumer impulsiveness: a cost-benefit accessibility framework. J Consum Psychol. 1996;5(2):87-113.

23. National Pharmaceutical Control Bureau; Ministry of Health Malaysia. Drug Registration Guidance Document, revised January 2016. Petaling Jaya: National Pharmaceutical Control Bureau; 2013.

24. Neoh CF, Zainal IN, Hameed MA, Khan TM, Ming LC. Development and progress of pharmacoinformatics in pharmaceutical and health sciences. J Young Pharm. 2015;7(3):155-63.

25. Pharmaceutical Services Division; Ministry of Health. A National Survey on the Use of Medicines (NSUM) by Malaysian Consumers 2012. Petaling Jaya: Pharmaceutical Services Division; 2013.

26. Mancinelli MD, Kafai YB. First Impression Processes: Awareness, Comprehension, and Opinion-Formation and Their Effect on Implementation of State Policies. Ph. D. Thesis, Faculties of the University of Pennsylvania, USA. (2014).

27. Tomaskovic DD, Leiter J, Thompson S. Organisational survey nonresponse. Adm Sci Q. 1994;39:439-57.

28. Groves RM. Nonresponse rates and nonresponse bias in household surveys Public Opin Q. 2006;70:646-75.

29. Rogelberg S, Stanton J. Understanding and dealing with organizational survey nonresponse. Organ Res Methods. 2007;10:195-209. 